\title{
Potential Nutrient Conversion Using Nature-Based Solutions in Cities and Utilization Concepts to Create Circular Urban Food Systems
}

\author{
Maria Wirth $^{1}$ (D) $\cdot$ Tamara Vobruba $^{1} \cdot$ Marco Hartl $^{1} \cdot$ Johannes Kisser $^{1}$
}

Received: 27 February 2021 / Accepted: 14 June 2021 / Published online: 13 July 2021

(C) The Author(s) 2021

\begin{abstract}
The present food system is characterized by a linear flow of resources from rural areas into cities, where most food is consumed and essential nutrients discharged as wastewater. Limited water and phosphorus resources and large carbon footprints of chemical fertilizers drive increased recovery of water and nutrients for reuse in agriculture. Alongside end-of-pipe technologies at conventional wastewater treatment plants, nature-based solutions provide a robust and low-energy alternative solution. This paper assesses the potential of treatment processes using NBS to close water and nutrient cycles in the urban food system. A Substance Flow Analysis approach is used to quantify the recoverable urban nutrient (nitrogen, phosphorus, potassium) budget contained in household wastewater and biodegradable kitchen waste, using the city of Vienna, Austria, as an example. The developed model reflects the metabolization of water and nutrients by treatment wetlands and biogas digesters into fertigation water and fertilizer. It differentiates between specific crop nutrient requirements and yields, and by greenhouse and outdoor farming conditions in a temperate climate. Results indicate that, using NBS, the wastewater and kitchen waste from 77,250 persons could fully cover the nitrogen and phosphorus fertilizer demand of the entire vegetable production in Vienna, which currently supplies one-third of Vienna's vegetable consumption. Additional people connected to the system can supply significant excess nutrients to produce other crops within and beyond the city. The model can inform selection and design of NBS for nutrient recovery and reuse, and support integrated planning regarding use of secondary nutrient sources and optimization of secondary nutrient utilization.
\end{abstract}

Keywords Circular economy · Urban food system - Nature-based solutions · Resource recovery · Urban planning $\cdot$ Urban wastewater

Maria Wirth

maria.wirth@alchemia-nova.net

Extended author information available on the last page of the article 


\section{Introduction}

The present-day food system is characterized by a one-directional flow of resources from rural areas into cities. Cities consume $75 \%$ of natural resources, produce $50 \%$ of global waste, and $60-80 \%$ of greenhouse gas emissions [13], a large proportion of which are directly associated with the urban food system [14]. The major share of essential macronutrients for agriculture is provided as chemical fertilizer that relies on limited resources (e.g., phosphorus) and with its production and use contributing the most significant part of overall agricultural greenhouse gas emissions [9].

The nutrients contained in the consumed food are discharged via urban sanitation systems, and largely removed by treatment processes and lost to potential reuse, with recovery technologies being adopted only slowly [26]. Each year, humans excrete around 3 million tons of phosphorus [8] equal to around $20 \%$ of annual global consumption of phosphate fertilizer [15]. Further, globally more than $70 \%$ of water is consumed for agricultural irrigation [53]. Given the ongoing tendency of growing population in cities, water and nutrient recovery from urban wastewater bears large and growing potential to sustain food supply in cities and the overall transition to a circular economy [4]. Conventional sanitation systems are not fit to adapt to the effects of climate change, such as increased stormwater flows and water scarcity [17] and food insecurity exacerbated by water scarcity [50]. Instead of collecting and removing potential water and nutrient resources, sanitation systems could be redesigned to contribute to resilient food systems and cities.

Therefore, resource recovery from urban wastewater has gained increasing attention. Alongside end-of-pipe technologies to recover nitrogen and phosphorus at conventional wastewater treatment plants (WWTPs), such as mono-incineration for phosphorus recovery, a range of nature-based solutions (NBS) for wastewater treatment can be applied to recover water, nutrients, materials, and energy, including the production of irrigation water and nutrients from domestic wastewater for safe reuse in urban and peri-urban agriculture [27]. NBS are robust, resilient technologies and can treat wastewater with minimal chemical and energy footprints, including the effective removal of a range of organic micropollutants [11, $25,54]$. If integrated into the built environment of a city, they can provide multiple benefits of vegetation and ecosystems, such as reducing urban heat islands. NBS are defined by the European Union (EU) as solutions that are "inspired and supported by nature, which are costeffective, simultaneously provide environmental, social and economic benefits and help build resilience. Such solutions bring more, and more diverse, nature and natural features and processes into cities, landscapes and seascapes, through locally adapted, resource-efficient and systemic interventions" [16].

This paper focuses on the combination of treatment wetlands (TW) for treatment of solidfree wastewater and anaerobic digestion for treatment of sludge and municipal sourceseparated organic waste (MOW, kitchen waste). TW for wastewater treatment are wellestablished NBS [51]. They can treat wastewater from a wide range of sources besides domestic wastewater, such as industrial (e.g., [11, 21, 31, 32] and agricultural wastewater (e.g., [2, 3, 49]) or landfill leachate [36], and have been successfully implemented in different climate zones around the world [19]. The systems are characterized by low external energy demand, comparatively low cost, and easy operation and maintenance as well as the possibility to use local materials and labor. Moreover, the treated water can be reused for a wide range of applications including agricultural irrigation (e.g., [5, 30]). Another advantage of this naturebased treatment technology is that it adds an aesthetic and regenerative value to a landscape or 
urban environment and provides ecosystem services including wildlife habitats, ambient air cooling through evapotranspiration, rainwater, and runoff storage as well as treatment [31, 32].

Biogas plants are a simple and low-cost technology to transform organic waste into energy and organic fertilizer. In combination, TW and biogas plants can efficiently treat liquid and solid fractions of wastewater, respectively, and the solid wastewater fraction (sewage sludge) co-digested with kitchen waste. Appropriate agricultural residues and industrial effluents, such as food and drink processing wastewater [21, 31, 32], wood, leather, and textiles wastewater $[2,3,20,29,37]$, could be added as well. TW fed with solid-free wastewater can function with reduced space and innovative setups which can be integrated into the built environment, such as green walls (e.g., [54]). This way, façades and other vertical structures may be utilized for greening and water treatment, additionally to suitable roof top and ground-level areas. While higher surface area demand is usually seen as a disadvantage, a larger greened area will also provide ecosystem services, such as heat island mitigation and aesthetics, to a greater degree.

This paper aims to contribute to a better understanding of the potential of NBS to close water and nutrient cycles in the urban-agricultural system. Specifically, this study aims to quantify the water and nutrients (nitrogen, phosphorus, potassium) that could be recovered, the fertilizer requirements that could be supplied by these recovered resources for the vegetable production in the city of Vienna, and recoverable excess nutrients and water which could be used for additional urban farming or transferred to agriculture beyond the city. To this end, a Substance Flow Analysis (SFA) approach is used to develop a resource conversion model and thereby assess urban nutrient budgets that could be recovered and reused in cities using NBS in the treatment train. The reuse potential of water and nutrients in household wastewater and kitchen waste is assessed on the basis of their metabolization in a recovery and reuse system combining the TW and anaerobic digester (biogas plant) steps and different crop nutrient requirements and yields, as well as greenhouse versus outdoor farming conditions in the temperate central European climate zone. The recovery and reuse system described in further detail in "Nutrient Recovery and Reuse Potential" below is based on the concept of the EUfunded HOUSEFUL project to close water and nutrient cycles in buildings.

\section{Materials and Methods}

\section{Urban Nutrient Budget}

The resource conversion model is developed using Substance Flow Analysis (SFA) [7], centered around the mass balance principle. The model used herein is developed on a unit conversion basis, with recoverable water, nutrients, and food calculated based on the number of people connected to the resource recovery and reuse system. In the present paper, the potential of recovered water and nutrients is calculated for the example of the City of Vienna, thus a city with the population size of 1.92 million in the year 2020 [43]. The water and nutrient (nitrogen $(\mathrm{N})$, phosphorus $(\mathrm{P})$, and potassium $(\mathrm{K})$ ) budgets are based on the domestic wastewater and food waste produced by the specified number of people, and assuming that $100 \%$ of their wastewater and food waste are made available within the city. Thus, there is no differentiation between people working and living in the defined system.

The values for water and nutrients contained in municipal wastewater per person are quantified based on the literature review and model values derived by Jönsson et al. [23]. Specifically, the values for household blackwater combined with household greywater (here 
including kitchen wastewater) are used, i.e. domestic wastewater, reflecting the common single piping system in buildings, i.e. without source separation. This does not include wastewater from industry and peri-urban agriculture, or stormwater, which otherwise may flow into the municipal sewage system. All values drawn from Jönsson et al. [23] were extrapolated from the given average daily values to annual values.

\section{Nutrient Recovery and Reuse Potential}

The treatment train, upon which the present model is based, is specified as follows. Unsegregated building wastewater is captured after it leaves the building and flows into a primary settling tank, from which the soluble fraction of the wastewater flows to a TW and the solid fraction in form of sludge is co-digested with kitchen waste in an anaerobic digester (biogas plant). The effluent of the TW is used as fertigation water containing the recoverable nutrients $(\mathrm{N}, \mathrm{P}, \mathrm{K})$. The effluent of the anaerobic digestion (digestate) is used as liquid fertilizer.

\section{Separation of Wastewater into Liquid and Solid Fractions}

The liquid and solid fractions of wastewater are separated in a primary settling (or sedimentation) tank after leaving the building and are further treated separately. This first step is further referred to as liquid-solid separation (LSS). The retention of suspended solids in primary settling tanks, and therefore the expected separation efficiency in form of sludge, is highly variable, with rarely distinguishable results ranging from 50-70\% [24]. For this study, the separation efficiencies of $50 \%$ was used. The nutrients are accounted as soluble and particulate fractions following Jönsson et al. [23]. These chosen values describe the composition of the wastewater as it leaves the building itself, thus already including the products of the fastest conversions (e.g., urea hydrolysis), which already occur within the sewage pipe system of the building. Particulate N, P, and K in the urine, feces and toilet paper, and household greywater streams, respectively, are distributed to the solid and liquid fraction in proportion to the assumed liquid-solid separation efficiency (50 to $70 \%$ ). Soluble N, P, and K are fully accounted to the liquid fraction.

\section{Treatment Wetlands}

The values for long-term removal rates of horizontal flow (HF) and vertical flow (VF) TW provided by Dotro et al. [12] were used as a basis to estimate the nutrient metabolization within the TW and the conversion factor from nutrient input to the content in the TW effluent. The parameters total nitrogen (TN), total phosphorus (TP) and $\mathrm{K}$ were used. While total nitrogen (TN) consists of $\mathrm{N}_{\text {org }}, \mathrm{NH}_{4}-\mathrm{N}, \mathrm{NO}_{3}-\mathrm{N}$, and $\mathrm{NO}_{2}-\mathrm{N}$, the two plant-available $\mathrm{N}$ forms, $\mathrm{NH}_{4}{ }^{+}$and $\mathrm{NO}_{3}{ }^{-}$, usually make up the vast majority of $\mathrm{TN}$ in the in- and effluent of TW fed with pretreated domestic wastewater. Therefore, other forms of $\mathrm{N}$ are neglected for the purpose of this publication. In order to provide a conservative estimation of recoverable nutrient content in the TW effluent, the average of the maximum removal rates of TN by HF and VF TW (35\%) and the maximum removal rates of TP $(20 \%)$ were used. $\mathrm{K}$ is rarely investigated, but four studies of TW for domestic WW treatment that monitored K removal were identified [10, 18, 34, 47] and the average of the provided K removal rates (44.95\%) was used.

As SSF systems can be designed and constructed so that they operate all year long even in temperate and cold climates [22, 45], the produced effluent volume was assumed to be 
relatively stable over the year. However, since there is a seasonal variation of fertigation water demand, the effluent will only be reused for the period of time during which fertigation is possible, i.e. 8 months a year, because in Austria, fertilizer application to regular crop fields is not permitted for 4 months per year [52].

\section{Anaerobic Digestion of Solid Wastewater Fraction and Kitchen Waste}

The present flow model considers the anaerobic co-digestion of separated sewage sludge (solid fraction) with source-separated municipal organic waste (MOW, kitchen waste). For MOW, the average kitchen waste in Austria of $68.79 \mathrm{~kg}$ per person and year is used, which consists of kitchen waste from food and drink provision outside homes as well as household sourceseparated kitchen waste and the compostable fraction of household mixed waste [40]. MOW nutrient content is calculated based on Knoop et al. [28]. Values for NPK and water in sewage sludge before co-digestion are based on Jönsson et al. [23]. In line with Möller and Müller [33], the $\mathrm{N}, \mathrm{P}$, and $\mathrm{K}$ content in absolute values is calculated as unchanged between the undigested influent and the digested effluent. It is assumed that digestate can easily be stored, thus the calculation uses $100 \%$ of nutrients recovered via digestate.

\section{Crop Nutrient Requirements and Yield by Area}

The nutrient requirements of food crops are calculated for the product groups defined in statistics on agricultural production in Vienna for the year 2018 [44]. Agriculture in Vienna includes the city and the green belt surrounding the city within Vienna's provincial boundaries. The average nutrient requirements per $\mathrm{m}^{2}$ and average harvest yields per $\mathrm{m}^{2}$ of specific crop types, differentiated by outdoor field and greenhouse cultivation, were taken from the Swiss guidelines for fertilizer application [35]. Specifically, net $\mathrm{N}, \mathrm{P}$, and $\mathrm{K}\left(\mathrm{N}, \mathrm{P}_{2} \mathrm{O}_{5}, \mathrm{~K}_{2} \mathrm{O}\right)$ requirements are used, which express the difference between total crop $\mathrm{N}, \mathrm{P}$, and $\mathrm{K}$ requirements and the nutrients available in undepleted soil, including those made available by leaving harvest residues on the fields and taken up by succeeding crops. It is assumed that by supplying the net nutrient requirements, the crops take up this amount from the soil and the nutrient balance in the soil is maintained. Thus, in this case, the equivalent amount introduced as fertilizer is absorbed by plants.

$\mathrm{P}$ and $\mathrm{K}$ contained in harvest residues are calculated as being fully transferred to the succeeding crop. Therefore, the $\mathrm{P}$ and $\mathrm{K}$ that must be added (i.e., net nutrient requirements) amount to approximately the $\mathrm{P}$ and $\mathrm{K}$ that is contained in the marketable product ([35]). As only $20 \%$ of the $\mathrm{N}$ left on fields as harvest residues can be taken up by succeeding crops ([35]), the $\mathrm{N}$ that directly travels back to consumers as food is calculated as the values for gross $\mathrm{N}$ fertilizer requirements minus the values for plant-available $\mathrm{N}$ in residues in Neuweiler [35] extrapolated to $100 \%$ (i.e., total $\mathrm{N}$ left on field). The present calculations are aggregated to annual values; hence, variations of nutrient uptake during the crop growth cycles are not differentiated. Production in greenhouses and open fields was apportioned to the specific crops produced in Vienna based on Schwarzl and Weiß [41].

\section{Water Flow}

The crop water requirements (irrigation water demand) that could be supplied with reclaimed fertigation water as well as the nutrient concentrations contained in it are calculated as follows. 
Table 1 Values used to investigate nutrients, vegetable yield, and water volumes that could be recovered and reused for irrigation

\begin{tabular}{|c|c|c|}
\hline Parameter & Value & Source \\
\hline $\begin{array}{l}\text { Nutrient content in wastewater fractions } \\
\text { (here only totals of all raw WW fractions } \\
\text { are listed) }\end{array}$ & $\begin{array}{l}\mathrm{N}: 13.68 \mathrm{~g} / \text { person per day } \\
\mathrm{P}: 1.92 \mathrm{~g} / \text { person per day } \\
\mathrm{K}: 4.00 \mathrm{~g} / \text { person per day }\end{array}$ & {$[23]$} \\
\hline Liquid-solid separation & $50 \%$ & {$[24]$} \\
\hline $\mathrm{TN}$ and TP removal by TW & TN: $35 \%$, TP: $20 \%$ & {$[12]$} \\
\hline $\mathrm{K}$ removal by $\mathrm{TW}$ & $44.95 \%$ & Average of [10]; [18]; [34]; [47] \\
\hline Average MOW in Austria & $68.79 \mathrm{~kg} /$ person per year & [40] \\
\hline Nutrient content of MOW & $\begin{array}{l}\mathrm{N}: 20.1 \mathrm{~g} / \mathrm{kg} \mathrm{DM} \\
\mathrm{P}: 3.5 \mathrm{~g} / \mathrm{kg} \mathrm{DM} \\
\mathrm{K}: 10.6 \mathrm{~g} / \mathrm{kg} \mathrm{DM}\end{array}$ & {$[28]$} \\
\hline NPK removal in anaerobic digestion & No removal & {$[33]$} \\
\hline NPK demand by crop types & {$\left[\mathrm{g} / \mathrm{m}^{2}\right.$ per year $]$} & Calculated based on [35] \\
\hline Fruity vegetables & $18.08 \mathrm{~N}, 2.55 \mathrm{P}, 19.29 \mathrm{~K}$ & \\
\hline Cabbage, leafy, pole vegetables & $17.23 \mathrm{~N}, 1.77 \mathrm{P}, 13.24 \mathrm{~K}$ & \\
\hline Pulses, root, bulb vegetables & $10.67 \mathrm{~N}, 1.65 \mathrm{P}, 12.69 \mathrm{~K}$ & \\
\hline Edible vegetable yield & & {$[35]$} \\
\hline Fruity vegetables & $8.64 \mathrm{~kg} / \mathrm{m}^{2}$ per year & \\
\hline Cabbage, leafy, pole vegetables & $3.06 \mathrm{~kg} / \mathrm{m}^{2}$ per year & \\
\hline Pulses, root, bulb vegetables & $4.25 \mathrm{~kg} / \mathrm{m}^{2}$ per year & \\
\hline Current production in Vienna & For the year 2018 & {$[44]$} \\
\hline Fruity vegetables & $52,218 \mathrm{t}$ & \\
\hline Cabbage, leafy, pole vegetables & $16,527 \mathrm{t}$ & \\
\hline Pulses, root, bulb vegetables & $3,851 \mathrm{t}$ & \\
\hline Wastewater produced & $128 \mathrm{~L} /$ person per day & {$[23]$} \\
\hline Solids subtracted & $144.3 \mathrm{~g} /$ person per day & [23] \\
\hline Losses via transpiration of TW & $1078.5 \mathrm{~L} / \mathrm{m} 2$ per year & [46] \\
\hline Precipitation & $550 \mathrm{~L} / \mathrm{m} 2$ per year & [39] \\
\hline Wetland area & $4 \mathrm{~m} 2 /$ person & [38] \\
\hline Crop water demand & $330 \mathrm{~L} / \mathrm{m} 2$ per year & [39] \\
\hline
\end{tabular}

The available treated effluent is the difference between the influent volume and transpiration from the TW, plus average annual precipitation. The influent volume consists of the wastewater produced by people connected to the system excluding the total solids contained in it. Total solids are excluded because the aim is to understand the extent to which the recovered effluent could supply the irrigation water demand of the vegetable field area, and including solids could otherwise lead to overestimating the irrigation potential. The value for the transpiration rate is calculated as an average of the two common wetland plant species used in the European temperate climate zone, Phragmites australis $\left(1,128 \mathrm{~L} / \mathrm{m}^{2}\right)$ and Carex acutiformis $\left(1,029 \mathrm{~L} / \mathrm{m}^{2}\right)$, cited as a reference for Vienna in a report by the City of Vienna [46]. The average annual precipitation of $550 \mathrm{~mm} \mathrm{[39]} \mathrm{is} \mathrm{used.} \mathrm{The} \mathrm{size} \mathrm{of} \mathrm{the} \mathrm{wetland} \mathrm{area}$ required was dimensioned according to the Austrian Standard [38] with $4 \mathrm{~m}^{2}$ per person equivalent (PE) for vertical flow (VF) TW.

To quantify the influent, the average wastewater production per person of $128 \mathrm{~L}$ per day is used, subtracting total solids (TS) values as provided in Jönsson et al. [23].

For crop water demand, the annual irrigation water demand for outdoor-cultivated field vegetables of $330 \mathrm{~mm}$ is used (ÖWAV Regelblatt 407, [39]). This value is based on the average annual precipitation and the average soil conditions in Austria. As all values are aggregated to yearly values, the crop water demand refers to the average across all growth stages. For the area of greenhouse cultivation, precipitation must be fully supplemented by 
irrigation. Open field and greenhouse production areas in Vienna were approximated and apportioned to crop types based on [41]. The values for mentioned calculations are presented in Table 1 below.

\section{Results and Discussion}

\section{Potential of Nature-Based Nutrient Cycles}

\section{Nutrient Recovery Efficiencies}

Table 2 below presents the nutrients discharged per person as well as by the 1.92 million population of Vienna [43] to the urban sewers via raw wastewater, as well as additionally via compostable household waste (municipal organic waste-MOW), every year. Table 2 also presents the nutrients that are contained in the recovered TW effluent and therefore could be applied to agricultural fields as fertigation water, as well as the nutrients contained in the biogas digestate. These values are based on 50\% liquid-solid separation (LSS) efficiency. Finally, Table 2 presents the conversion efficiencies from N, P, and $\mathrm{K}$ input to nutrients recovered in nutrient solutions, i.e. contained in fertigation water and digestate fertilizer applicable to fields.

With the majority of nutrients contained in raw wastewater and TW effluent (in contrast to MOW, solids in wastewater, and recovered digestate), the removal rates of TW strongly determine the amount of nutrients that could be recovered. The removal rates for $\mathrm{N}(35 \%)$ and $\mathrm{P}(20 \%)$ used in the present study are based on Dotro et al. [12]. However, nutrient removal rates reported in recent literature vary a lot. For example, Tanner et al. [48] report 8.9 to $49.0 \%$ TN removal and 39.0 to $>55.0 \%$ TP removal. Morari and Giardini [34] report even 91.0\% TN removal and $72.5 \%$ TP removal in a pilot-scale vertical subsurface flow TW. Tables S1A and S1B (see supplementary material) provide an overview of nutrient removal efficiencies of TW treating municipal wastewater found in literature. The overview includes TW at scales from 1 to $6,080 \mathrm{~m}^{2}$ in different countries worldwide.

The studies presented in Tables S1A and S1B (see supplementary material) focus on subsurface flow (SSF) TW. The authors consider SSF TW to be well suited for densely settled areas due to their lower area requirement, minimum odor development, and provision of a barrier between the wastewater and the surroundings through the subsurface flow, i.e. mitigating contact of humans or animals with wastewater, in contrast to free water surface (FWS) wetland systems.

Table 2 Nutrients contained in raw WW, MOW, and TW effluent and digestate, as well as the resulting conversion efficiencies

\begin{tabular}{|c|c|c|c|c|c|c|c|}
\hline & \multicolumn{2}{|l|}{ Per person } & \multicolumn{4}{|c|}{ Total Vienna } & \multirow[b]{2}{*}{ Conversion efficiencies } \\
\hline & Raw WW & MOW & Raw WW & MOW & TW effluent* & Digestate & \\
\hline $\mathrm{N}$ & $5.0 \mathrm{~kg} / \mathrm{yr}$ & $0.4 \mathrm{~kg} / \mathrm{yr}$ & $9,587 \mathrm{t} / \mathrm{yr}$ & $828 \mathrm{t} / \mathrm{yr}$ & $3,846 \mathrm{t} / \mathrm{yr}$ & $1,336 \mathrm{t} / \mathrm{yr}$ & $51 \%$ \\
\hline $\mathrm{P}$ & $0.7 \mathrm{~kg} / \mathrm{yr}$ & $0.08 \mathrm{~kg} / \mathrm{yr}$ & $1,346 \mathrm{t} / \mathrm{yr}$ & $144 \mathrm{t} / \mathrm{yr}$ & $511 \mathrm{t} / \mathrm{yr}$ & $421 \mathrm{t} / \mathrm{yr}$ & $67 \%$ \\
\hline $\mathrm{K}$ & $1.5 \mathrm{~kg} / \mathrm{yr}$ & $0.2 \mathrm{~kg} / \mathrm{yr}$ & $2,803 \mathrm{t} / \mathrm{yr}$ & 437 t/yr & $1,029 \mathrm{t} / \mathrm{yr}$ & $437 \mathrm{t} / \mathrm{yr}$ & $45 \%$ \\
\hline
\end{tabular}

*if TW effluent is reused for 8 months per year 
The mentioned calculated values for nutrient conversion from MOW to recovered digestate correspond well to the nutrient content of digestate from co-digestion of MOW and municipal sewage sludge analyzed by Sogn et al. [42]. This suggests that the method applied in the present study is suitable to quantify recoverable nutrients from MOW and solids separated from municipal sewage processed by anaerobic digestion.

While nutrients are preserved to a greater degree in biogas digesters, the recovery of nutrients by a TW brings the added benefits of (urban) greening as well as the supply of fertigation water, which can easily be applied to fields especially for vegetable production, which is commonly irrigated even in temperate climates such as in Austria. Digestate may need to be hygienized before application to food crops. There are several options to hygienize the digestate, such as sludge composting, a sludge treatment wetland or other TW designs depending on the solids content, or dry fermentation. Another option is to simply extend the retention time in the digester so that no additional hygienization step should be necessary if the digestion process works properly.

In the present study, it was assumed that the population of Vienna spends $100 \%$ of the day ( $24 \mathrm{~h}$ ) within the system, in this case the city, and therefore, the total amount of wastewater produced by them enters the calculation. When quantifying the urban nutrient budget for a city or another urban scale (e.g., district, quarter, building), the number of people and the share of the day spent within the boundaries of the city could be further differentiated. For example, Jönsson et al. [23] suggest dividing the 24-h day into 60\% active (awake) time out of a day spent at work and $40 \%$ spent at home. This could be multiplied by the people residing in the area of scope, and those commuting in and out of the city (or district, quarter, or building).

The conversion efficiencies above refer to the process from raw wastewater and MOW to recovered nutrient solutions. But looking at the full cycle, the efficiency of the recovery and reuse system is impacted by the actual utilization by crops and the valorization as food. As mentioned in "Materials and Methods," if the N:P:K ratio of the nutrient solution added to soil as fertigation water or fertilizer corresponds to that of the specific crop nutrient demand and crops take up their net nutrient requirements from the soil, the nutrient balance in the soil is assumed to remain the same, and $100 \%$ of added nutrients are used. However, if the N:P:K ratio of the recovered nutrient solution does not correspond to the $\mathrm{N}: \mathrm{P}: \mathrm{K}$ ratio of specific crop net nutrient demand and NPK are added to fully cover the requirements of each N, P, and K, there will be excess application of the nutrients that are available to a larger proportion. This results in losses (unutilized nutrients) and lower conversion efficiencies from raw "waste" input to the food products.

\section{Linking Recoverable NPK to Crop Nutrient Demand}

To supply the entire vegetable production within Vienna, per year, total $212.04 \mathrm{t} \mathrm{N}, 26.4 \mathrm{t} \mathrm{P}$, and 199.6 $\mathrm{t} \mathrm{K}$ must be added as fertilizer (net nutrient demand). The wastewater and MOW produced by 77,250 people, metabolized by the described system, could supply total $212.05 \mathrm{t}$ $\mathrm{N}, 39.9 \mathrm{t} \mathrm{P}$, and $59.0 \mathrm{t} \mathrm{K}$ as recovered fertigation water (TW effluent) and liquid fertilizer (biogas digestate) per year. This would cover the $\mathrm{N}$ demand and exceed the amount of $\mathrm{P}$ needed for the whole actual vegetable production in Vienna.

Around one-third of vegetables consumed in Vienna is produced within the city boundaries (Stadtentwicklung Wien, n.d.). Therefore, if the vegetable consumption patterns by product groups are similar to production, 231,750 people could supply all the $\mathrm{N}$ and $\mathrm{P}$ needed to produce all vegetables consumed in Vienna. Nutrients that could be recovered if the entire 
population of Vienna would be connected to described nature-based treatment trains amount to 25 times the N, 37 times the P, and 7 times the K needed to sufficiently supply the net nutrient requirements of the approximated production of all vegetables consumed by Vienna's population. The significant excess nutrients recovered from wastewater and MOW could supply the production of other food groups (fruit, grain) and feed and industrial crops to fully close the resource loop within the city and between the city and its agricultural hinterland.

Figure 1 illustrates the nutrient flows from consumers through the treatment steps to agricultural production and via food back to the consumers. The flows represent $\mathrm{N}$ (beige arrows), $\mathrm{P}$ (blue arrows), and $\mathrm{K}$ (orange arrows) that is emitted via wastewater and MOW by the 1.9 million population of Vienna. Non-edible food parts are not included in the diagram, because they are considered to be left on the field and become a source of nutrients to the crops, or they travel back to the consumer as part of marketable vegetables and then become kitchen waste, re-entering the recovery and reuse system.

Figure 1 highlights that, while municipal organic waste is widely processed to compost and even biogas, municipal wastewater (the flow from consumers to liquid solid separation) is a much more significant untapped resource. Further, only a small fraction of the recovered nutrients are needed to cover the peri-urban Viennese vegetable production, which, as mentioned, covers one-third of the entire vegetable consumption in the city. The excess nutrients could be recovered and returned to other agricultural production within and beyond the city's borders. Even if nutrients from the entire (non-industrial) urban wastewater and MOW are recovered and returned to food production, there is a smaller flow returning to consumers than is emitted by consumers. This gap could be filled by recovering nutrients from landscaping waste and livestock manure, which are already widely processed by composting and anaerobic digestion. Figure 1 also showcases that $\mathrm{K}$ is contained in the liquid wastewater fraction and recovered fully via the TW.

Figure 2 below showcases that the $\mathrm{N}$ that could be recovered from municipal wastewater and MOW produced by 77,250 people could cover the net $\mathrm{N}$-fertilizer demand of the entire vegetable production of Vienna; recoverable $\mathrm{P}$ even exceeds the demand, while $\mathrm{K}$ must be added from another source. Consistent with previous research, availability of $\mathrm{K}$ is relatively low in human excreta (e.g., [1]), and consistently in overall treated municipal wastewater (e.g., [6]). K could be supplemented with sustainable and cheap K sources such as biomass ash or

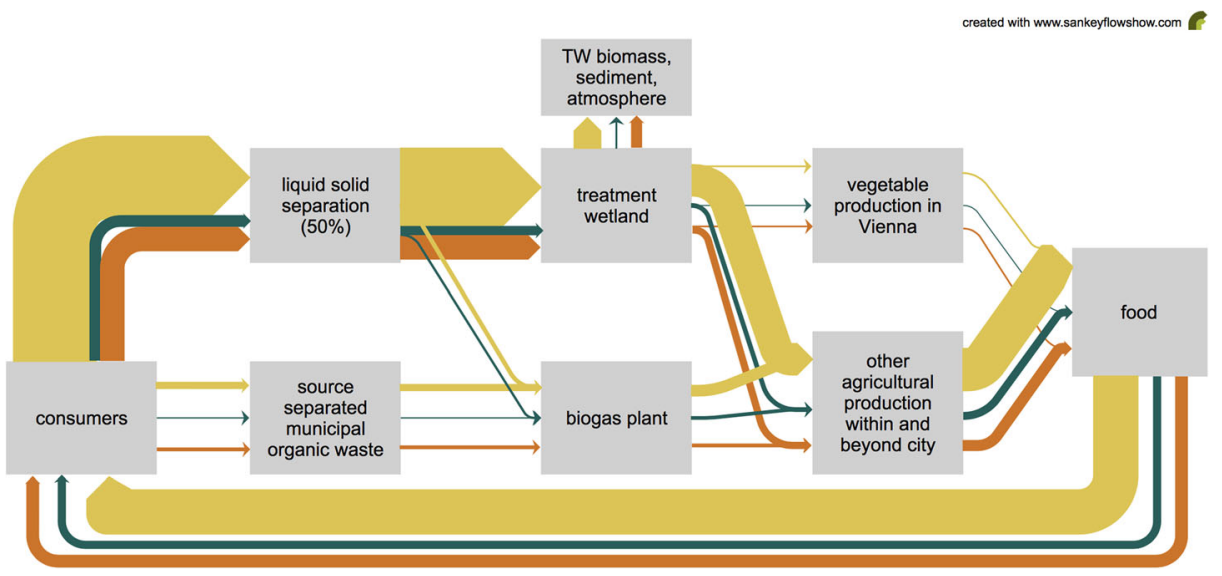

Fig. 1 Potential nutrient (NPK) loop in the city of Vienna 
[t/yr]

250

200

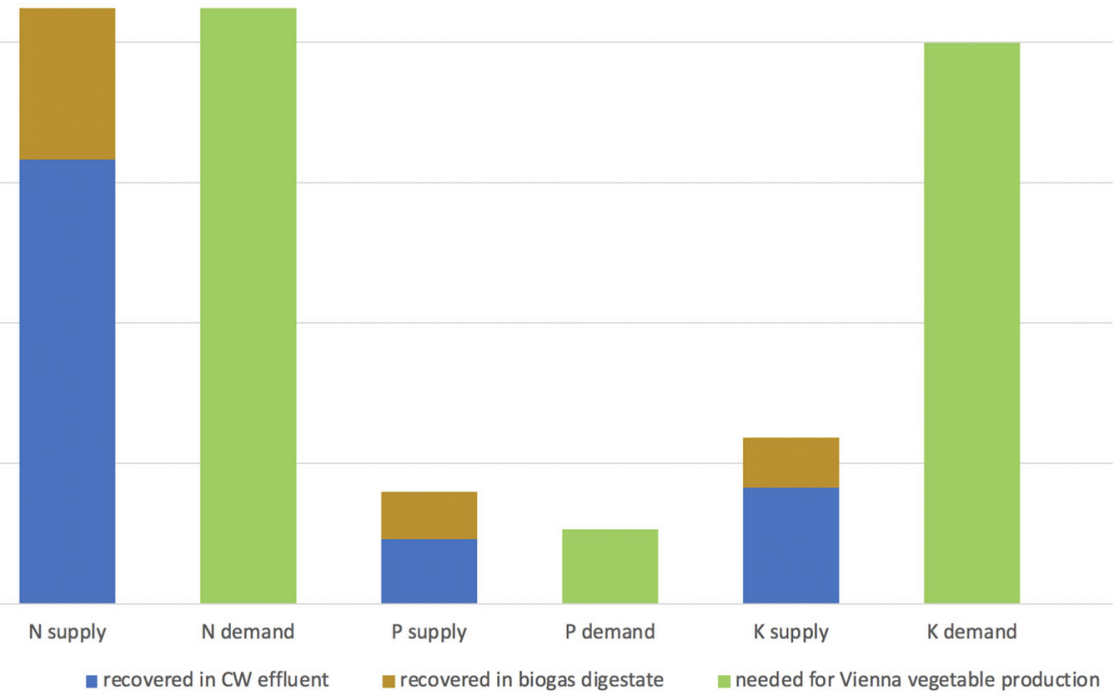

Fig. 2 NPK supply in TW effluent and biogas digestate from 77,250 people vs. demand for vegetable production in Vienna

livestock manure. $\mathrm{K}$ in ash is soluble and can be extracted by washing ash. Even though livestock manure adds not only $\mathrm{K}$, but also $\mathrm{N}$ and $\mathrm{P}$, the share of $\mathrm{K}$ content is so high that the addition of livestock manure easily fills (and can exceed) the $\mathrm{K}$ gap [1, 6]. Livestock manure could be co-digested with solids and landscaping waste.

Figure 2 also displays the shares of nutrients supplied by TW effluent and digestate, considering a $50 \%$ LSS (i.e., $50 \%$ of solids are retained, the rest join the liquid fraction). As shown, the TW effluent supplies most of the N (75\%), P (58\%), and K (70\%). Compared to $70 \%$ LSS, these ratios hardly change, with the TW effluent supplying $71 \% \mathrm{~N}, 70 \% \mathrm{~K}$, and $49 \%$ P, i.e., biogas digestate supplies just over half of recovered P (51\%) with $70 \%$ LSS.

\section{Adaptation of Nutrient Sources to Product Groups to Optimize the Recovery and Reuse Efficiency}

As mentioned above, the plant macronutrients $\mathrm{N}, \mathrm{P}$, and $\mathrm{K}$ are allocated to the three vegetable product groups in proportion to their actual share of total vegetable production in Vienna, namely $49 \%$ fruity vegetables (product group 1), $44 \%$ cabbage, leafy, and pole vegetables (product group 2), and 7\% pulses, root, and bulb vegetables (product group 3) (Stadt Wien, n.d.). This distribution could be adapted to specific crop production of any defined community, city, region, or country.

$\mathrm{N}: \mathrm{P}$ ratio of nutrient demand for Viennese vegetable production is $8: 1$, which is the same as the N:P ratio of the TW effluent, if LSS is $70 \%$. Therefore, for the described combination of crops, the TW effluent is a suitable nutrient source. The N:P ratio of recovered nutrient solutions (TW effluent and digestate combined) is 5:1 and the digestate has an N:P ratio of 
3:1, due to higher relative P-levels. The N:P ratios change with a lower LSS. In the case of $50 \%$ LSS, the N:P ratio in the TW effluent sinks to 1:7, which still corresponds more closely to the $\mathrm{N}: \mathrm{P}$ ratio of crop nutrient demand of the vegetables produced in Vienna than the combination of TW effluent and digestate or digestate alone. This suggests that the net $\mathrm{N}$ and $\mathrm{P}$ fertilizer requirements of the vegetable crop mix produced in Vienna are best met by using the TW effluent, or by combining TW effluent and digestate as nutrient sources.

The N:P:K ratio required to meet Viennese vegetable production is $8: 1: 8$, while the $\mathrm{N}: \mathrm{P}: \mathrm{K}$ ratio of TW effluent is 8:1:2, for 70\% LSS. This reflects the shortage of K noted above. A look at the specific nutrient distributions to the solid and liquid fraction of municipal wastewater reveals that there is no $\mathrm{K}$ in the solid fraction. The $\mathrm{K}$ in recovered digestate comes from the MOW co-digested with the solid wastewater fraction. If digestate is to be used as fertilizer, the solid wastewater fraction should be co-digested with MOW to gain $\mathrm{K}$, or liquids and solids codigested, which however eliminates the benefits of functional greening and ecosystem services that TW can provide.

This knowledge and present model can inform the selection of sources to match the crop nutrient demand (considering $\mathrm{N}: \mathrm{P}$ or $\mathrm{N}: \mathrm{P}: \mathrm{K}$ ratios), and thereby also to maximize the use efficiency of recoverable nutrients.

Figure 3 below shows the area that could be sufficiently supplied with nutrients from fertigation water and digestate, if either only product group 1 (fruity vegetables), group 2 (cabbage, leafy, and pole vegetables), or group 3 (pulses, root, and bulb vegetables) are produced. The variety of areas across the product groups and nutrients reflects the different crop nutrient requirements of NPK per $\mathrm{m}^{2}$ as well as NPK availability in recovered fertigation water and digestate fertilizer. For example, average product group 1 vegetables demand higher $\mathrm{K}$ input per field area than product groups 2 and 3. Therefore, $\mathrm{K}$ limits the field area that could be fertigated so that crops obtain sufficient NPK. Conversely, the area of fields cultivating group 3 products that could be fertigated with available $\mathrm{K}$ is much higher than for groups 1 and 2. Groups 2 and 3 vegetables require similar P per area. For the scenario that only fruity

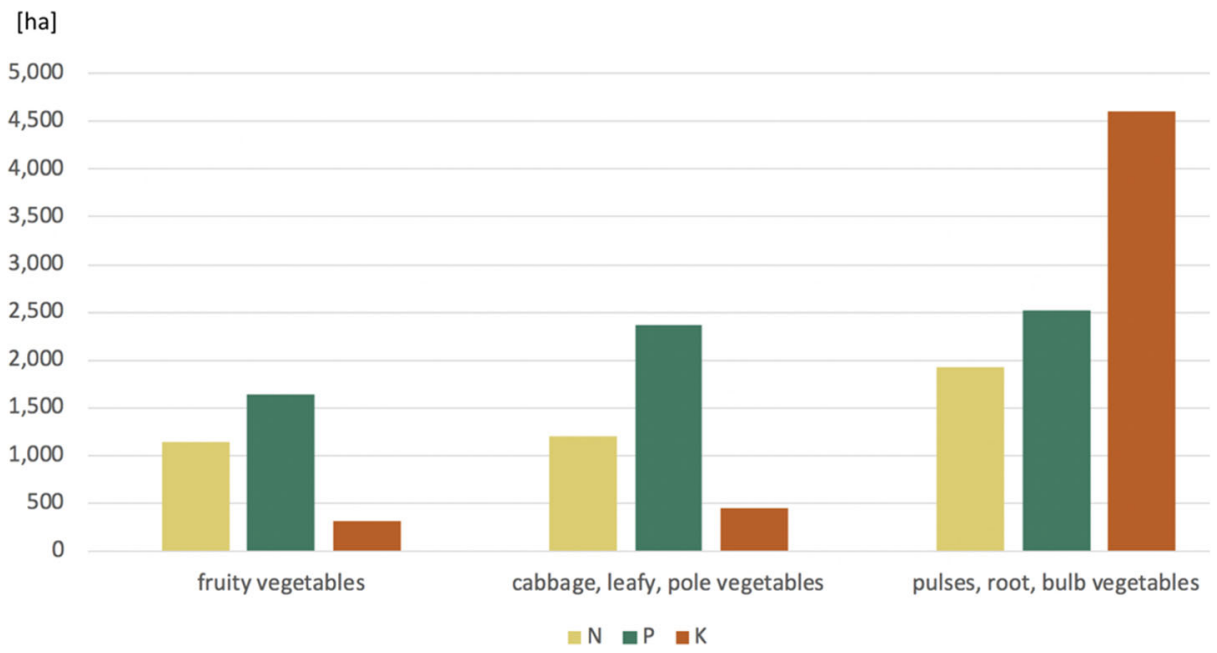

Fig. 3 Field area sufficiently supplied with NPK from 100,000 PE for production of either product group 1, group 2, or group 3 
vegetables are produced and $\mathrm{K}$ is supplemented, $\mathrm{N}$ represents the limiting value and an area of 1,140 ha could be sufficiently supplied with recovered nutrients. If only pulses, root, or bulb vegetables are produced, with a selection of group 3 vegetables representing the average nutrient demand, and $\mathrm{K}$ is supplemented, then again $\mathrm{N}$ represents the limiting value and 1,933 ha could be supplied.

Meanwhile, K could relatively easily be added by adding organic waste-based pot-ash, which is generally considered sustainable and cost-efficient. If $\mathrm{N}: \mathrm{P}: \mathrm{K}$ ratios in recovered nutrient supply sources and specific crop field demand are considered, crop selection and/or dimensioning of the system could be adapted to N:P:K ratios in the fertigation water (TW effluent), or fertilizer (digestate) in order to maximize the production achieved from applying only recovered nutrients, and/or to maximize the replacement of synthetic fertilizer. The calculations for this study were conducted with average net nutrient requirements of different crop species within each product group (1-3). When applying this to a specific field case, the specific crop nutrient requirements could be considered and secondary nutrient input sources tapped adequately.

As mentioned, matching the N:P:K ratio of recovered macronutrient solutions with the $\mathrm{N}: \mathrm{P}: \mathrm{K}$ ratios of crop net nutrient requirements would minimize the losses and increase the conversion and utilization efficiencies. The optimization is beyond the scope of this paper, but in practice, this could be done by comparing the net nutrient requirements of specific cultivated crops with the recoverable nutrient sources and adapt the mix of nutrient sources (household wastewater, MOW, green clippings, livestock wastewater, other wastewaters), sustainable and waste-based specific nutrient supplements, treatment technologies and specific designs, or even selected crop mix. How much discrepancy between NPK ratios results in lower quantity or quality of production should be looked at in further detail.

\section{Water Flow}

From the yearly $89,702,400 \mathrm{~m}^{3}$ of municipal wastewater produced by the total population of Vienna, a volume of $57,028,263 \mathrm{~m}^{3}$ of fertigation water could be recovered as TW effluent, if accessing it during 8 months per year. This includes water recovered from the municipal wastewater and precipitation captured by the TW. For greenhouse cultivation, the average annual precipitation must be supplemented, which results in an average annual irrigation water demand of $880 \mathrm{~L} / \mathrm{m} 2$. Considering the recommended irrigation of outdoor-cultivated field vegetables and mentioned compensation of precipitation in greenhouse-cultivated vegetables (see "Materials and Methods" above), the total vegetable production in Vienna requires 8,787,527 $\mathrm{m}^{3}$ irrigation water per year, cultivated on an area of 1,235 ha. This is equivalent to recovering the wastewater produced by 151,600 people. The secondary fertigation water that could be produced by treating and reusing the wastewater generated by the total population of Vienna could cover the irrigation demand of 15,643 ha of vegetable field area, if the shares of production in greenhouses and open fields are maintained. This is equivalent to the 13-fold actual field area of vegetable production within the boundaries of Vienna.

The potential irrigable area reduces with greater greenhouse production and increases if the share of open field production is larger, due to compensating precipitation in greenhouse irrigation. 


\section{Area Requirements and Integration into the Urban Infrastructure}

Table 1 below shows the nutrients that could be recovered from the wastewater and MOW produced by a five-person household, the potential vegetable yield resulting from these secondary nutrients, and the area needed for the TW and the field area that could be supplied with nutrients considering the vegetable product group proportions produced in Vienna. A single household could supply a field area of $938 \mathrm{~m}^{2}$ and would require a TW of approximately $20 \mathrm{~m}^{2}$, considering the $4 \mathrm{~m}^{2}$ TW area per PE set out in the Austrian standard for TW [38] (Table 3).

Connecting the 77,250 people, thus treating the amount of wastewater to fully supply Viennese vegetable production with recovered nutrients, an area of 31 ha is needed. To treat the wastewater produced by the whole Viennese population, 768 ha would be needed.

As mentioned above, the specific TW area of $4 \mathrm{~m}^{2}$ per PE is set out in the Austrian standard for TW [38]. However, it does not reflect more recent technical advances that enable smaller TW size per PE while fulfilling legal effluent water quality requirements. Thus, the $4 \mathrm{~m}^{2}$ are a conservative estimation, and this area could be reduced by implementing available enhanced NBS with design improvements which enable sizing of less than $4 \mathrm{~m}^{2}$ per PE. Such design improvements can include, for example, multi-stage systems, using different substrates or intensification through aeration and/or recirculation. TW size could also be reduced if wastewater reuse is the goal instead of treatment for disposal, and therefore nutrients could be preserved instead of removed. Though in this case, firstly, the removal of pollutants that may threaten human health must still be ensured, and secondly, the effluent water quality must always comply with national standards or laws for water reuse (e.g., the Regulation (EU) 2020/ 741 on minimum requirements for water reuse for agricultural irrigation) or for wastewater treatment for disposal.

TW can also be designed and installed as green façade panels or stacked units, with basins stacked above each other, thus reducing the actual ground-space needed.

Moreover, the vast available unused or underutilized open spaces in cities as well as rooftops could be used for functional urban greening providing not only the increasingly necessary climate services in cities (evaporative cooling, biodiverse habitats), but also treat building wastewater for on-site recovery and reuse for urban farming. Designing green urban infrastructures with wastewater treatment abilities would also reduce the need for synthetic fertilizer and drinking water which existing urban greening, in particular intensive systems, currently relies on.

Table 3 Recovered nutrients for a five-person household, corresponding vegetable yield, and area needed for the TW and vegetable cultivation

\begin{tabular}{|c|c|c|c|c|c|c|c|c|}
\hline & \multicolumn{3}{|c|}{ Recovered nutrients } & \multicolumn{3}{|c|}{ Vegetable yield (product groups) } & \multicolumn{2}{|c|}{ Area needed } \\
\hline & $\mathrm{N}$ & $\mathrm{P}$ & $\mathrm{K}$ & 1 & 2 & 3 & $\begin{array}{l}\text { TW } \\
\text { area }\end{array}$ & $\begin{array}{l}\text { Cultivation } \\
\text { area }\end{array}$ \\
\hline $\begin{array}{l}\text { Five-person } \\
\text { household }\end{array}$ & $14 \mathrm{~kg} / \mathrm{yr}$ & $3 \mathrm{~kg} / \mathrm{yr}$ & $4 \mathrm{~kg} / \mathrm{yr}$ & $3,462 \mathrm{~kg} / \mathrm{yr}$ & $\begin{array}{l}1,580 \\
\mathrm{~kg} / \mathrm{yr}\end{array}$ & $393 \mathrm{~kg} / \mathrm{yr}$ & $20 \mathrm{~m}^{2}$ & $938 \mathrm{~m}^{2}$ \\
\hline $\begin{array}{l}\text { Total in } \\
\text { Vienna }\end{array}$ & $\begin{array}{r}5,270 \\
\mathrm{t} / \mathrm{yr}\end{array}$ & $\begin{array}{l}991 \\
\mathrm{t} / \mathrm{yr}\end{array}$ & $\begin{array}{r}1,466 \\
\mathrm{t} / \mathrm{yr}\end{array}$ & $\begin{array}{c}1,329,463 \\
\text { t/yr }\end{array}$ & $\begin{array}{c}606,736 \\
t / y r\end{array}$ & $\begin{array}{c}150,906 \\
\text { t/yr }\end{array}$ & 768 ha & 36,025 ha \\
\hline
\end{tabular}


Finally, the size of the TW could be reduced if the goal is not to remove, but to metabolize and even preserve nutrient content from wastewater in the nutrient solutions recovered as effluents. However, it must be noted that reclaimed water may not contain nutrients only, but could contain a wide range of contaminants as a result of our lifestyle (e.g., pharmaceutical residues, biocides, disinfectants). Therefore, when designing a recovery and reuse system, not only the nutrient mass balance but also health and safety issues must be considered before any such system could be put in place. Several studies have found that TWs can partly remove organic micropollutants, in some cases more effectively than conventional WWTPs [25, 54]. Therefore, TWs have been installed to treat wastewater from pharmaceuticals and cosmetics industry [11] besides other municipal and industrial effluents. To ensure food safety when irrigating crops with reclaimed water treated by NBS, further research could investigate the design requirements of technologies and the combination within the treatment system to effectively remove organic micropollutants and other potentially harmful substances such as microplastics and heavy metals. Additional treatment steps that do not remove nutrients could be included, such as ozonation.

At the building or household scale in cities, there is limited space to utilize the nutrients, public infrastructure is largely not designed for this, nor can economies of scale be used. However, the ecosystem services of distributed NBS, the efficiency gains of direct cycles, and the supported maintenance through localized ownership could be exploited. At the neighborhood, district, or communal scale, limited economies of scale can be use, and local space for farming and composting may be available. At the urban centralized scale, space for large-scale treatment may be available at the outskirts and distributed treatment units across the city could be implemented. Collection systems are already widely in place, as the management and regulatory frameworks to implement resource recovery and redistribution for reuse with centralized organization. Economies of scale allow high-tech control systems. However, if resources are recovered centrally, potential inefficiencies may be incurred by longer distances across which resources must be transported for treatment and redistribution to the point of reuse.

Instead of fully replacing the centralized, conventional wastewater treatment systems in large cities with NBS, various different types of TW could be integrated into the existing urban built infrastructure, in particular in new buildings or new urban development areas. In particular in peri-urban areas, which are located close to agricultural production, the proposed nature-based resource recovery and reuse system could be implemented to close water and nutrient cycles locally and contribute to a circular economy, a more climate-friendly food system and resilient city.

\section{Conclusions}

This study quantified the recoverable nutrient budget contained in household wastewater and MOW, with the example of the city of Vienna, Austria. The results of the SFA highlight the enormous untapped potential of available secondary resources. TW together with anaerobic digestion of the solid wastewater fraction can treat the wastewater and MOW, and make nutrients accessible and plant-available in the effluent streams. The present results indicate that NBS could be used to recover sufficient nutrients to produce the vegetables consumed by the entire population connected to the resource recovery and reuse system, which consists of the described treatment train and the application of nutrient solutions to vegetable fields. Based on 
the conversion factors used, the $\mathrm{N}$ and $\mathrm{P}$ recovered from wastewater and $\mathrm{MOW}$ of 77,250 persons could fully cover the fertilizer demand of the whole vegetable production in Vienna, while 231,750 persons could supply Vienna's entire vegetable consumption. Most of the nutrients are recovered via the TW effluent. Around half of $\mathrm{P}$ is contained in recovered TW effluent and digestate. Consistent with previous literature, there is a shortage of $\mathrm{K}$ when considering only household water and MOW. But K could be supplemented in a sustainable way. Knowledge of N:P:K ratios of secondary resources, conversion efficiencies of the treatment train, and crop nutrient requirements could inform the selection of inputs as well as the design and combination of the treatment units in order to optimize the use of available nutrients, while also benefitting from the ecosystem services provided by NBS, and energy generated by biogas units.

By connecting the wastewater and MOW of additional people to the nature-based recovery and reuse system, excess nutrients could be used to produce other food groups and feed and industrial crops within and beyond the city. The nutrients that could be recovered by connecting the entire 1.92 million population of Vienna to the recovery and reuse system amount to 25 times the N, 37 times the $\mathrm{P}$, and 7 times the $\mathrm{K}$ needed to produce all vegetables consumed in Vienna. The annual $57,028,263 \mathrm{~m}^{3}$ of reclaimed water is sufficient to irrigate 15,643 ha of vegetable production area, which is the 13 -fold actual field area of vegetable production in Vienna. In this sense, cities could become significant water and nutrient turntables for the whole bioeconomy even well beyond food production.

Nature-based wastewater treatment and complementary components of the resource recovery and reuse systems require more space than conventional technologies. They also require a change in the way wastewater, and urban built infrastructure is used, managed, and developed. However, NBS as productive greening could be integrated into the urban and peri-urban system to start gaining from the benefits of circular intensive urban greening as well as from decentralized water and nutrient treatment and reuse.

Further research could refine the described resource conversion model according to available (underutilized) infrastructures in the urban and peri-urban space, changes at different scales, and design requirements to remove potentially remaining pathogens as well as agricultural production in and around the city, to fully close the loops. While the technologies to realize such a system are available, a host of non-technical barriers remain to be further investigated, as well as case specific strategies considering type and location of waste sources across the city, physical infrastructures available for the installation of TW (including vertical and rooftop units) and anaerobic digesters, and finally the development of suitable business models.

List of Abbreviations $T W$, treatment wetland; $E U$, European Union; $F W S$, free water surface; $L S S$, liquid-solid separation; $M O W$, Municipal source-separated organic waste; $N B S$, nature-based solutions; $P E$, person equivalent; $S F A$, Substance Flow Analysis; $S S F$, subsurface flow; $K$, potassium; $T N$, total nitrogen; TP, total phosphorus; TSS, total suspended solids; $V W$, vertical flow; WWTPS, wastewater treatment plants

Supplementary Information The online version contains supplementary material available at https://doi.org/ 10.1007/s43615-021-00081-6.

Acknowledgements The authors want to mention and thank the Horizon 2020 HOUSEFUL project (grant agreement no 776708) for supporting this publication.

Code Availability Not applicable. 
Funding The research was supported by the European Union (HOUSEFUL project). This project has received funding from the European Union's Horizon 2020 research and innovation programme under grant agreement No 776708 .

Data Availability All data and material supporting the findings of this study are either available within the article, the supplementary material, or are available from the corresponding author on request.

\section{Declarations}

Competing Interests The authors declare no competing interests.

Open Access This article is licensed under a Creative Commons Attribution 4.0 International License, which permits use, sharing, adaptation, distribution and reproduction in any medium or format, as long as you give appropriate credit to the original author(s) and the source, provide a link to the Creative Commons licence, and indicate if changes were made. The images or other third party material in this article are included in the article's Creative Commons licence, unless indicated otherwise in a credit line to the material. If material is not included in the article's Creative Commons licence and your intended use is not permitted by statutory regulation or exceeds the permitted use, you will need to obtain permission directly from the copyright holder. To view a copy of this licence, visit http://creativecommons.org/licenses/by/4.0/.

\section{References}

1. Akram U, Quttineh NH, Wennergren U, Tonderski K, Metson G (2019) Enhancing nutrient recycling from excreta to meet crop nutrient needs in Sweden - a spatial analysis. Sci Rep 9:10264. https://doi.org/10.1038/ s41598-019-46706-7

2. Akratos CS, Oirschot DV, Tekerlekopoulou AG, Vayenas DV, Stefanakis AI (2018a) Dairy wastewater treatment with constructed wetlands: experiences from Belgium, the Netherlands and Greece. In: Constructed Wetlands for Industrial Wastewater Treatment. John Wiley \& Sons, Ltd, pp 175-202. https://doi.org/10.1002/9781119268376.ch9

3. Akratos CS, Tekerlekopoulou AG, Vayenas DV (2018b) Treatment of wastewater from tanneries and the textile industry using constructed wetland systems. In: Constructed Wetlands for Industrial Wastewater Treatment. John Wiley \& Sons, Ltd, pp 0-0. https://doi.org/10.1002/9781119268376.ch16

4. Almuktar SAAAN, Abed SN, Scholz M (2018) Wetlands for wastewater treatment and subsequent recycling of treated effluent: a review. Environ Sci Pollut Res 25:23595-23623. https://doi.org/10.1007/ s11356-018-2629-3

5. Arden S, Ma C (2018) Constructed wetlands for greywater recycle and reuse: a review. Sci Total Environ 630:587-599

6. Arienzo M, Christen E, Quayle WC, Kumar A (2009) A review of the fate of potassium in the soil-plant system after land application of wastewaters. J Hazard Mater 164:415-422. https://doi.org/10.1016/j. jhazmat.2008.08.095

7. Bringezu S, van de Sand I, Schütz H, Bleischwitz R, Moll S (2009) Analysing global resource use of national and regional economies across various levels. In: Sustainable Resource Management. Global Trends, Visions and Policies. Greenleaf, Sheffield, pp 10-52

8. Childers DL, Corman J, Edwards M, Elser JJ (2011) Sustainability challenges of phosphorus and food: solutions from closing the human phosphorus cycle. BioScience 61:117-124. https://doi.org/10.1525/bio. 2011.61.2.6

9. CropLife International (2012) The carbon footprint of crop protection products. CropLife International. https:/www4.unfccc.int/sites/SubmissionsStaging/Documents/201811071654\%2D\%2D-CLI\% 20Submission\%20Carbon\%20Footprint.pdf. Accessed 31.5.2021

10. De Monte HM, Albuquerque A (2010) Analysis of constructed wetland performance for irrigation reuse. Water Sci Technol 61:1699-1705. https://doi.org/10.2166/wst.2010.063

11. Dordio A, Carvalho AJP (2018) Removal processes of pharmaceuticals in constructed wetlands. In: Constructed Wetlands for Industrial Wastewater Treatment. John Wiley \& Sons, Ltd, pp 343-403. https://doi.org/10.1002/9781119268376.ch17

12. Dotro G, Langergraber G, Molle P, Nivala J, Puigagut J, Stein O, von Sperling M (2017) Treatment wetlands, biological wastewater treatment series. IWA Publishing, London 
13. Ellen MacArthur Foundation (2017) Urban Biocycles

14. Ellen MacArthur Foundation, 2017. Urban Biocycles. Ellen MacArthur Foundation. https://www. ellenmacarthurfoundation.org/assets/downloads/publications/Urban-Biocycles EllenMacArthurFoundation 21-06-2017.pdf. Accessed 31.5.2021

15. Elser B, Bennett E (2011) A broken biogeochemical cycle. Nature 478:29-31. https://doi.org/10.1038/ 478029a

16. European Commission (2020) Nature-based solutions projects tackle the climate and biodiversity crisis. https://ec.europa.eu/easme/en/section/horizon-2020-environment-and-resources/nature-based-solutionsprojects-tackle-climate-and. Accessed 2.5.21

17. European Environment Agency (2021) Briefing. Urban waste water treatment for 21 st century challenges. Publications. https://www.eea.europa.eu/publications/urban-waste-water-treatment-for/urban-waste-watertreatment. Accessed 5.30.21

18. Eustáquio Júnior VE, De Matos AT, Lo Monaco PAV, De Campos LC, Borges AC (2012) Eficiência de sistemas alagados construídos cultivados com aveia preta no tratamento de esgoto doméstico. Acta Sci Technol 34:391-398. https://doi.org/10.4025/actascitechnol.v34i4.13990

19. Global Wetland Technology (2021) References. Glob. Wetl. Technol. https://www.globalwettech.com/ references.html. Accessed 3.5.21

20. Gomes AC, Stefanakis AI, Albuquerque A, Simões R (2018) Cork Boiling wastewater treatment in pilot constructed wetlands. In: Constructed Wetlands for Industrial Wastewater Treatment. John Wiley \& Sons, Ltd, pp 283-308. https://doi.org/10.1002/9781119268376.ch14

21. Hartl M, Hogan J, Ioannidou V (2018) Treatment of effluents from meat, vegetable and soft drinks processing using constructed wetlands In: Constructed Wetlands for Industrial Wastewater Treatment. John Wiley \& Sons, Ltd, pp 145-162. https://doi.org/10.1002/9781119268376.ch7

22. Jenssen PD, Mæhlum T, Krogstad T, Vråle L (2005) High performance constructed wetlands for cold climates. J Env Sci Heal Part Toxic Hazardous Subst Env Eng 40:1343-1353. https://doi.org/10.1081/ESE200055846

23. Jönsson H, Baky A, Jeppsson U, Hellström D, Kärrman E (2005) Composition of urine, feaces, greywater and biowaste for utilisation in the URWARE model., Urban Water report. Chalmers University of Technology, Gothenburg

24. Jover-Smet M, Martín-Pascual J, Trapote A (2017) Model of suspended solids removal in the primary sedimentation tanks for the treatment of urban wastewater. Water 9:448. https://doi.org/10.3390/w9060448

25. Kaur R, Talan A, Tiwari B, Pilli S, Sellamuthu B, Tyagi RD (2020) Chapter 5 - Constructed wetlands for the removal of organic micro-pollutants. In: Current Developments in Biotechnology and Bioengineering. Emerging Organic Micro-Pollutants. Elsevier, pp 87-140

26. Kehrein P, Van Loosdrecht M, Osseweijer P, Garfí M, Dewulf J, Posada J (2020) A critical review of resource recovery from municipal wastewater treatment plants - market supply potentials, technologies and bottlenecks. Environ Sci Water Res Technol 6:877-910. https://doi.org/10.1039/C9EW00905A

27. Kisser J, Wirth M, De Gusseme B, Van Eekert M, Zeeman G, Schoenborn A, Vinnerås B et al (2020) A review of nature-based solutions for resource recovery in cities. Blue-Green Syst 2:138-172. https://doi.org/ $10.2166 /$ bgs.2020.930

28. Knoop T, Tietze M, Dornack C, Raab T (2018) Fate of nutrients and heavy metals during two-stage digestion and aerobic post-treatment of municipal organic waste. Bioresour Technol 251:238-248. https:// doi.org/10.1016/j.biortech.2017.12.019

29. Kumar S, Choudhary AK (2018) Constructed wetland technology for pulp and paper mill wastewater treatment. In: Constructed Wetlands for Industrial Wastewater Treatment. John Wiley \& Sons, Ltd, pp. 309-325. https://doi.org/10.1002/9781119268376.ch15

30. Masi F, Martinuzzi N (2007) Constructed wetlands for the Mediterranean countries: hybrid systems for water reuse and sustainable sanitation. Desalination 215:44-55. https://doi.org/10.1016/j.desal.2006.11.014

31. Masi F, Rizzo A, Bresciani R (2018a) Treatment of wineries and breweries effluents using constructed wetlands. In: Constructed Wetlands for Industrial Wastewater Treatment. John Wiley \& Sons, Ltd, pp 95104. https://doi.org/10.1002/9781119268376.ch4

32. Masi F, Rizzo A, Regelsberger M (2018b) The role of treatment wetlands in new circular economy, resource oriented, and ecosystem services paradigms. J Environ Manage 2016:275-284. https://doi.org/10. 1016/j.jenvman.2017.11.086

33. Möller K, Müller T (2012) Effects of anaerobic digestion on digestate nutrient availability and crop growth: a review: digestate nutrient availability. Eng Life Sci 12:242-257. https://doi.org/10.1002/elsc.201100085

34. Morari F, Giardini L (2009) Municipal wastewater treatment with vertical flow constructed wetlands for irrigation reuse. Ecol. Eng. 35:643-653. https://doi.org/10.1016/j.ecoleng.2008.10.014

35. Neuweiler R (2011) Düngungsrichtlinien für den Gemüseanbau. Forschungsanstalt Agroscope ChanginsWädenswil ACW, Wädenswil 
36. Nivala J, Wallace S (2010) Treatment of landfill leachate in aerated subsurface flow wetlands: two case studies. In: Water and Nutrient Management in Natural and Constructed Wetlands. Springer Science and Business Media LLC, Dordrecht, The Netherlands, pp. 121-131

37. Ong SA, Uchiyama K, Inadama D, Ishida Y, Yamagiwa K (2010) Treatment of azo dye Acid Orange 7 containing wastewater using up-flow constructed wetland with and without supplementary aeration. Bioresour Technol 101:9049-9057

38. ÖNORM B 2505 (2009) Kläranlagen - Intermittierend beschickte Bodenfilter ("Pflanzenkläranlagen") Anwendung, Bemessung, Bau, Betrieb, Wartung und Überprüfung

39. ÖWAV (2016) ÖWAV-Regelblatt 407: Empfehlungen für die Bewässerung - Überarbeitete Neuauflage des ÖWAV-Arbeitsbehelfs Nr. 11 (2003). Austrian Standards, Vienna

40. Scherhaufer S, Hrad M, Unger N, Obersteiner G (2016) Datenlage zu Lebensmittelabfallmengen in Österreich. Institut für Abfallwirtschaft, Universität für Bodenkultur Wien, Vienna

41. Schwarzl B, Weiß M (2017) SUM-FOOD: Regionale Lebensmittelpfade am Beispiel der Stadt Wien für die Produktgruppe Gemüse (No. REP-0621). Umweltbundesamt GmbH, Vienna

42. Sogn TA, Dragicevic I, Linjordet R, Krogstad T, Eijsink VGH, Eich-Greatorex S (2018) Recycling of biogas digestates in plant production: NPK fertilizer value and risk of leaching. Int J Recycl Org Waste Agric 7:49-58. https://doi.org/10.1007/s40093-017-0188-0

43. Stadt Wien (2021) Bevölkerungsstand - Statistiken. URL https://www.wien.gv.at/statistik/bevoelkerung/ bevoelkerungsstand/. Accessed 2.5.21

44. Stadt Wien (n.d.) Gemüseproduktion in den Bundesländern nach Produktgruppen 2018. Wirtsch. Arb. Stat. URL https://www.wien.gv.at/statistik/wirtschaft/tabellen/gemueseernte-bundeslaender.html. Accessed 2.5. 21

45. Stein OR, Hook PB (2005) Temperature, plants, and oxygen: how does season affect constructed wetland performance? J Env Sci Heal Part ToxicHazardous Subst Env Eng 40:1331-1342. https://doi.org/10.1081/ ESE-200055840

46. Stundner W (2014) Regenwasserbewirtschaftungsbecken als Teil des nach haltigen Regenwassermanagements in Wien. MA 22 - Umweltschutz, Vienna

47. Sudarsan JS, Roy RL, Baskar G, Deeptha VT, Nithiyanantham S (2015) Domestic wastewater treatment performance using constructed wetland. Sustain Water Resour Manag 1:89-96. https://doi.org/10.1007/ s40899-015-0008-5

48. Tanner CC, Sukias JPS, Headley TR, Yates CR, Stott R (2012) Constructed wetlands and denitrifying bioreactors for on-site and decentralised wastewater treatment: Comparison of five alternative configurations. Ecol Eng 42:112-123. https://doi.org/10.1016/j.ecoleng.2012.01.022

49. Tepe Y, Temel FA (2018) Treatment of effluents from fish and shrimp aquaculture in constructed wetlands, in: Constructed Wetlands for Industrial Wastewater Treatment. John Wiley \& Sons, Ltd, pp 105-125. https://doi.org/10.1002/9781119268376.ch5

50. UNESCO, UN-Water (2020) United Nations World Water Development Report 2020:Water and Climate Change. UNESCO, Paris

51. Vymazal J (2011) Constructed wetlands for wastewater treatment: five decades of experience. Environ Sci Technol 45:61-69. https://doi.org/10.1021/es101403q

52. Wasserrechtsgesetz" 1959, §55 und $\S 133$ Abs. 6, BGB1. I Nr. 58/2017. https://www.ris.bka.gv.at/ GeltendeFassung.wxe?Abfrage=Bundesnormen \&Gesetzesnummer=10010290. Accessed 12.7.2021

53. World Bank Group (2020) Water in Agriculture. World Bank. URL https://www.worldbank.org/en/topic/ water-in-agriculture. Accessed 3.5.21

54. Zraunig A, Estelrich M, Gattringer H, Kisser J, Langergraber G, Radtke M, Rodriguez-Roda I, Buttiglieri G (2019) Long term decentralized greywater treatment for water reuse purposes in a tourist facility by vertical ecosystem. Ecol Eng 138:138-147. https://doi.org/10.1016/j.ecoleng.2019.07.003

\section{Affiliations}

\section{Maria Wirth $^{1} \cdot$ Tamara Vobruba $^{1} \cdot$ Marco Hartl $^{1} \cdot$ Johannes Kisser $^{1}$}

1 alchemia-nova GmbH, Baumgartenstraße 93, 1140 Vienna, Austria 